\title{
Analysis of the EGFR Mutation Status in Head and Neck Squamous Cell Carcinoma before Treatment with Gefitinib
}

\author{
Sven Bontognali Miklos Pless $^{\mathrm{a}, \mathrm{b}, \mathrm{e}} \quad$ Martin H. Brutsche $\mathrm{e}^{\mathrm{a}, \mathrm{e}}$ \\ Claude Fischer $^{\mathrm{a}, \mathrm{c}, \mathrm{f}} \quad$ Christoph Rochlitz $^{\mathrm{a}, \mathrm{b}} \quad$ Martin Buess $^{\mathrm{a}, \mathrm{b}, \mathrm{g}}$

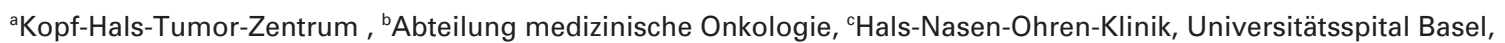 \\ ${ }^{\mathrm{d}}$ Tumorzentrum Kantonsspital Winterthur, ${ }^{\mathrm{e} P n e u m o l o g i e ~ K a n t o n s s p i t a l ~ S t . ~ G a l l e n, ~}{ }^{\mathrm{f}} \mathrm{ORL}-\mathrm{Klinik}$ Kantonsspital Graubünden, Chur, \\ ${ }^{9}$ St. Claraspital, Basel, Switzerland
}

\section{Keywords}

Gefitinib - Squamous cell carcinoma of the head and neck - EGFR - Predicitive

\section{Summary}

Background: The efficacy of chemotherapy in metastatic and recurrent squamous cell carcinomas of the head and neck (HNSCC) remains unsatisfactory. Gefitinib offers a new therapeutic option with comparable results and better tolerability than chemotherapy. We conducted this study to see if mutations in the epidermal growth factor receptor (EGFR) might predict the therapeutic benefit in HNSCC patients. Patients and Methods: In a pilot trial, 8 patients with metastatic or recurrent HNSCC were treated palliatively with gefitinib $(500 \mathrm{mg} /$ day orally). Forceps biopsies were taken to confirm tumor recurrence and to perform an EGFR mutation analysis. Results: The EGFR status could be determined in 6 of the 8 patients. 5 patients had no EGFR gene mutation, and 1 patient showed a silent guanine-to-adenosine mutation in position 2607. Even without any relevant mutation in the EGFR, we observed partial remission in 3 of 6 patients treated with gefitinib. We also observed that an additional 4 patients had stable disease for at least 10 weeks. The median progression-free survival was 6.25 months, and the median overall survival was 7.39 months. Conclusion: In HNSCC, there are tumor responses to gefitinib without protein-altering mutations in the EGFR gene.

\author{
Schlüsselwörter \\ Gefitinib - Plattenepithelkarzinom - Kopf-Hals-Tumor . \\ EGFR · Prädiktiv
}

\section{Zusammenfassung}

Hintergrund: Die Wirksamkeit der Chemotherapie ist bei metastasierten und rezidivierenden Plattenepithelkarzinomen des Kopfes und Halses (HNSCC) nach wie vor unbefriedigend. Gefitinib bietet eine neue therapeutische Option mit vergleichbaren Ergebnissen und besserer Verträglichkeit als die konventionelle Chemotherapie. Wir haben diese Studie durchgeführt, um zu evaluieren, ob eine Mutation im epidermalen Wachstumsfaktorrezeptor (EGFR) den therapeutischen Nutzen von Gefitinib bei HNSCC-Patienten vorhersagen könnte. Patienten und Methoden: In einer Pilotstudie wurden 8 Patienten mit metastasiertem oder rezidivierendem HNSCC palliativ mit Gefitinib (500 mg/Tag oral) behandelt. Es wurden Zangenbiopsien entnommen, um das Tumorrezidiv histologisch zu sichern und eine EGFRMutationsanalyse durchzuführen. Ergebnisse: Der EGFRStatus des Tumors konnte bei 6 von 8 Patienten bestimmt werden. 5 Patienten hatten keine Mutation des EGFR-Gens und ein Patient zeigte eine stille Mutation an Position 2607 von Guanin zu Adenosin. Auch ohne entsprechende Mutation im EGFR beobachteten wir eine partielle Remission bei 3 von 6 Patienten und weitere 4 Patienten mit stabiler Erkrankung für mindestens 10 Wochen. Das mediane progressionsfreie Überleben betrug 6,25 Monate und die mediane Gesamtüberlebenszeit betrug 7,39 Monate. Schlussfolgerung: Bei HNSCC gibt es ein Ansprechen von Tumoren auf eine Therapie mit Gefitinib auch ohne proteinverändernde Mutationen im EGFR-Gen.

\section{KARGER \\ Fax +497614520714 \\ Information@Karger.com}

www.karger.com (c) 2013 S. Karger GmbH, Freiburg

0378-584X/13/0364-0161\$38.00/0

Accessible online at:

www.karger.com/onk
PD Dr. med. Dr. phil. Martin Buess

St. Claraspital

Kleinriehenstrasse 30, 4016 Basel, Switzerland

Martin.Buess@claraspital.ch 


\section{Introduction}

The survival rates of patients with squamous cell carcinoma of the head and neck (HNSCC) have not much improved over the last decade [1]. Curative approaches are in competition with their functional and cosmetic outcomes, which significantly influence the patient's quality of life [2]. About half of the treated patients will relapse locally or with distant metastases. The treatment of recurrent and metastatic HNSCC is a major therapeutic challenge. The prognosis of patients with recurrent or metastatic HNSCC is generally poor, with a median survival of about 6 months [3]. Patients in good general condition and with locally recurrent disease can benefit again from either surgery or further radiotherapy [4]. For patients with metastatic or unresectable recurrent disease without the option for re-irradiation, conventional chemotherapy or targeted agents are the only treatment options.

The response rates with conventional chemotherapeutic agents generally reach $15-30 \%$ with a response duration of 3-5 months [5-7]. Several randomized trials have shown that combination chemotherapy showed a higher response rate, but this comes at the price of increased toxicity and without any significant survival advantage [8]. It has recently been shown for the first time that, in addition to conventional chemotherapy, a targeted agent against the epidermal growth factor receptor (EGFR), cetuximab, significantly improves the median overall survival (OS) by 2.5 months [9]. However, in second-line therapy, the response rates are minimal. In a multi-institutional retrospective analysis of 151 patients with progressive cancer following treatment with platinum-based therapy, the overall response rate was $2.6 \%$, and the median time to tumor progression with best supportive care, chemotherapy, radiotherapy, and radiochemotherapy was 45, 67, 131, and 153 days, respectively [10]. Novel therapeutic strategies are urgently needed.

The EGFR is overexpressed in up to $90 \%$ of HNSCC cases [11-13]. Malignant cells express 50-100 times more EGFR than normal keratinocytes [14]. Often, overexpression of the EGFR is associated with an increased production of EGFR ligands, which results in an autocrine stimulation of the tumor cells [15]. This autocrine signaling of EGF and EGFR may be blocked by EGFR antibodies like cetuximab or other smallmolecule inhibitors of the EGFR tyrosine kinase-1 [16]. One of these small-molecule inhibitors is gefitinib, a synthetic anilinoquinazoline. Gefitinib is taken orally and acts to selectively inhibit the EGFR tyrosine kinase [17]. In vitro and in vivo preclinical studies in tumor cell lines in mice showed a dose-dependent anti-proliferative effect of gefitinib [18]. As monotherapies, the EGFR inhibitors have modest overall activity with response rates of $1-11 \%$ for gefitinib [19] and erlotinib [20]. However, compared to a conventional chemotherapy regimen with methotrexate, gefitinib showed equal survival rates but fewer side effects [7].
From the experience with non-small-cell lung cancer, it is known that the response rates to gefitinib in an unselected patient population are disappointingly small [21]. However, some patients showed a tumor response that has not been previously observed in treatment with conventional chemotherapy. In a landmark study, Lynch et al. [22] were able to demonstrate that 8 of 9 patients with gefitinib-sensitive adenocarcinomas of the lung had a somatic mutation in the tyrosine kinase domain of the EGFR while no mutations were found in gefitinib-resistant cancers. The mutations detected were either small in-frame deletions or amino acid substitutions that accumulated near the ATP binding site of the tyrosine kinase domain.

The aim of this study was to determine whether there is a correlation between the tumor response of HNSCC to treatment with gefitinib and alterations in the EGFR. If so, the possibility might exist for a more targeted approach to treat HNSCC with gefitinib and improve its therapeutic efficacy.

\section{Patients and Methods}

In this pilot trial at the interdisciplinary head and neck cancer center of the Basel University Hospital, 8 patients with HNSCC were enrolled. The protocol was approved by the ethical committee of Basel (EKBB 97/03). Patients with recurrent and unresectable locoregional and/or distant metastatic HNSCC with either progressive disease after at least 1 prior chemotherapy or chemoradiotherapy regimen or patients with no better treatment options were eligible for the trial. Eligibility criteria included a life expectancy $>3$ months, an Eastern Cooperative Oncology Group (ECOG) performance status (PS) of $\leq 2$, and adequate hematologic, renal and liver function. Exclusion criteria included significant comorbidities (including coronary artery disease, symptomatic congestive heart failure, active alcohol abuse, bleeding diathesis, history of interstitial lung disease, or gastrointestinal ulcer within 12 months); concurrent use of phenytoin, carbamazepine, barbiturates, rifampicin, phenobarbital, or St John's wort; or surgery or radiotherapy within 30 days.

Treatment with gefitinib was provided free of charge by AstraZeneca as part of a compassionate use program. The planned regimen recommended that gefitinib be administered orally at a dose of $250 \mathrm{mg}$ twice daily within a treatment cycle of 28 days.

Tumor assessment for response took place at the end of every 2nd cycle (i.e., 8 weeks) of therapy. In patients completing 6 cycles of therapy, the evaluation for response was performed after every 3rd cycle. Response was assessed radiographically according to the Response Evaluation Criteria in Solid Tumors (RECIST) [23] and by physical examination. Patients with at least stable disease (SD) continued treatment with gefitinib until either tumor progression or unacceptable toxicity occurred. All patients were dead at the time of analysis. Progression-free survival (PFS) and OS were estimated from the start of therapy until disease progression or date of death.

\section{Method of EGF Receptor Mutation Analysis}

A forceps biopsy was taken for standard diagnostic purposes, and a second forceps biopsy was obtained for the current study during the same intervention. Both biopsies were put directly into the RNA preservation solution, RNA later (Ambion ${ }^{\circledR}$ ), kept for $1 \mathrm{~h}$ in a $-20^{\circ} \mathrm{C}$ freezer and then frozen and stored at $-80^{\circ} \mathrm{C}$. 


\section{RNA Isolation}

Total RNA was extracted using the optimized TRIZOL ${ }^{\circledR}$ reagent (Invitrogen). For this purpose, we followed the protocol of the RNeasy ${ }^{\circledR}$ Micro Kit for RNA purification, which included on-column DNase treatment to eliminate genomic DNA in the samples.

\section{Reverse Transcription}

For the reverse transcription (RT) of mRNA, $200 \mathrm{ng}$ of total RNA was mixed in a volume of $7 \mu \mathrm{l}$ with $3 \mathrm{mM}$ dT25 primer. To perform the annealing, the RNA and dT25 primer were kept for $10 \mathrm{~min}$ at $65^{\circ} \mathrm{C}$ and then immediately cooled on ice. The cDNA synthesis was carried out with the help of $1 \mu \mathrm{l}(100 \mathrm{U})$ of SuperScript ${ }^{\circledR}$ reverse transcriptase MMLV (Boehringer) in $12 \mu \mathrm{l}$ RT buffer (containing $200 \mathrm{mM}$ dNTP, $10 \mathrm{mM}$ dithiothreitol (DTT) and $40 \mathrm{U} \mathrm{RNAsin} 1^{\circledR}$ (Boehringer)) for $1 \mathrm{~h}$ at $42{ }^{\circ} \mathrm{C}$. The cDNA was stored at $-20{ }^{\circ} \mathrm{C}$ thereafter.

\section{Polymerase Chain Reaction}

To perform the polymerase chain reaction (PCR) for the amplification of exons 19-21 of the EGFR gene, the 18-mer primer EGFR-1 (GeneID: 1956, Consensus CDS: CCDS5514.1) forward (GCTTGTGGAGCCTCTTAC) and a 19-mer reverse primer (GGTGGGTATAGATTCTGTG) were used. The PCR was carried out in a volume of $50 \mu \mathrm{l}$, which included the buffer and the enzyme from the Advantage Klen Taq KIT $1^{\circledR}$ (Clontech). The reaction was carried out with $1 \mathrm{mM}$ of primers, $10 \mathrm{mM}$ dNTP and $5 \mu \mathrm{l}$ RT product as the template. For amplification, the following cycling protocol was used: $15 \mathrm{~s}$ at $94{ }^{\circ} \mathrm{C}, 30 \mathrm{~s}$ at $63{ }^{\circ} \mathrm{C}$, and $30 \mathrm{~s}$ at $72{ }^{\circ} \mathrm{C}$, for 35 cycles.

\section{Sequencing of PCR Products}

The sequencing of the PCR fragments was carried out after the cycle sequencing protocol and subsequent capillary electrophoresis according to the standard protocol of Microsynth AG (Balgach, Switzerland). When sequencing, the 21-mer primer GGAGCCTCTTACACCCAGTGG was used. The sequences were compared with the wild-type EGFR gene sequence using the Blast program.

\section{Results}

\section{Patient Characteristics}

HNSCC was confirmed in all patients by either cytology or histology. The initial diagnosis was established by the Institute of Pathology within the University of Basel between 1999 and 2003. The patient characteristics are given in table 1. Overall, the patients represented a population of mostly heavily pretreated patients who had either recurrent or metastatic disease.

\section{The Gefitinib Therapy}

Patients received a total of 53 cycles of treatment (median 7 cycles, range 1-12 cycles). 4 patients were treated with $500 \mathrm{mg}$ of gefitinib daily. In 2 of these patients, the dose had to be reduced to $250 \mathrm{mg} /$ day due to side effects during the course of the disease. In the other 2 patients, the full dose was used until discontinuation due to tumor progression occurred on days 78 and 258, respectively. The 4 other patients were treated with $250 \mathrm{mg}$ of gefitinib from the beginning of the study; a dose reduction was never necessary. The average duration of gefitinib therapy without a break was 190 days (range 43-333 days). On average, patients were
Table 1. Baseline characteristics of patients with HNSCC treated with gefitinib

\begin{tabular}{|c|c|}
\hline Variable & $\begin{array}{l}\text { Number of patients } \\
(\%)\end{array}$ \\
\hline \multicolumn{2}{|l|}{ Age at diagnosis, years } \\
\hline Median & 61.5 \\
\hline Range & $47-78$ \\
\hline \multicolumn{2}{|l|}{ Sex } \\
\hline Female & $1 / 8(12.5)$ \\
\hline Male & $7 / 8(87.5)$ \\
\hline \multicolumn{2}{|c|}{ Tumor, node, metastasis classification at diagnosis } \\
\hline T2 N0 M0 & $1 / 8(12.5)$ \\
\hline $\mathrm{T} 2 \mathrm{~N} 2 \mathrm{~b} \mathrm{M} 0$ & $1 / 8(12.5)$ \\
\hline T3 N2b M0 & $2 / 8(25)$ \\
\hline T3 N2c M1 & $1 / 8(12.5)$ \\
\hline T4 N2 M1 & $1 / 8(12.5)$ \\
\hline T4 N0 M0 & $1 / 8(12.5)$ \\
\hline No information & $1 / 8(12.5)$ \\
\hline \multicolumn{2}{|l|}{ Histology } \\
\hline Oropharyngeal carcinoma & $1 / 8(12.5)$ \\
\hline Carcinoma of the oral cavity & $2 / 8(25)$ \\
\hline Supraglottic laryngeal carcinoma & $1 / 8(12.5)$ \\
\hline Epi-/mesopharyngeal carcinoma & $1 / 8(12.5)$ \\
\hline Carcinoma of the alveolar process & $2 / 8(25)$ \\
\hline Temporal squamous cell carcinoma & $1 / 8(12.5)$ \\
\hline \multicolumn{2}{|l|}{ Smoking status } \\
\hline Yes & $6 / 8(75)$ \\
\hline No & $2 / 8(25)$ \\
\hline \multicolumn{2}{|l|}{ Alcohol } \\
\hline Yes & $4 / 8(50)$ \\
\hline No & $4 / 8(50)$ \\
\hline \multicolumn{2}{|l|}{ Pretreatment (before gefitinib) } \\
\hline None & $1 / 8(12.5)$ \\
\hline Surgery (a) & $0 / 8(0)$ \\
\hline Neck dissection (b) & $0 / 8(0)$ \\
\hline Radiotherapy (c) & $1 / 8(12.5)$ \\
\hline Chemotherapy (d) & $0 / 8(0)$ \\
\hline$a+b+c$ & $1 / 8(12.5)$ \\
\hline$a+b+c+d$ & $4 / 8(50)$ \\
\hline$c+d$ & $1 / 8(12.5)$ \\
\hline
\end{tabular}

treated with $500 \mathrm{mg} /$ day of gefitinib for 73 days (range 0-258 days) and with $250 \mathrm{mg}$ /day of gefitinib for 116 days (range 0-268 days). The average cumulative total dose was $65.9 \mathrm{~g}$ (range 10.7-129 g). The average cumulative total dose obtained was $69 \%$ of the expected total dose, which was equivalent to a dose reduction of $31 \%$. Reasons for discontinuation included tumor progression (2/8), death (4/8), and side effects $(2 / 8) .6$ patients received no further treatment after gefitinib, 1 patient received chemotherapy with cisplatin and 1 patient received chemotherapy with docetaxel, radiotherapy and bisphosphonate treatment after stopping gefitinib.

\section{Side Effects of Gefitinib Therapy}

The most common side effects of gefitinib therapy were varying degrees of skin rash and diarrhea. 6 patients had skin rashes greater than grade 2, and 2 patients had diarrhea greater than grade 2 . Because of these side effects, gefitinib therapy was either interrupted for various durations of time or a dose reduction to $250 \mathrm{mg} /$ day was made. After the introduction of these measures, a decline in side effects was observed in all patients, and treatment could be continued in 
all but 1 patient who died due to tumor progression soon after the dose reduction.

\section{Results of Gefitinib Therapy}

The tumor response evaluation was carried out according to the RECIST criteria. 3 patients had a partial response (PR), 4 patients had SD, and 1 patient had progressive disease (PD) (fig. 1). The median PFS was 6.25 months (range 1.310.8 months). The median OS was 7.4 months (range 4.110.8 months). The 3 patients without prior systemic therapy had a PFS of 2.6, 5.8, and 10.8 months, respectively, which is in the same range as for the patients previously treated with chemotherapy.

\section{Results of the EGF Receptor Mutation Analysis}

In 6 of 8 patients, an EGFR mutation analysis could be performed $(75 \%) .5$ patients had no mutation in the sequenced part of exons 19-21, and 1 patient had a silent guanine-toadenosine mutation in position 2607. In the other 2 patients, no sequence was obtained (table 2). The 2 tumors from which a sequence could not be obtained showed either SD or $\mathrm{PD}$ in response to therapy with gefitinib. Thus, the responses to gefitinib were independent of the EGFR mutation status.

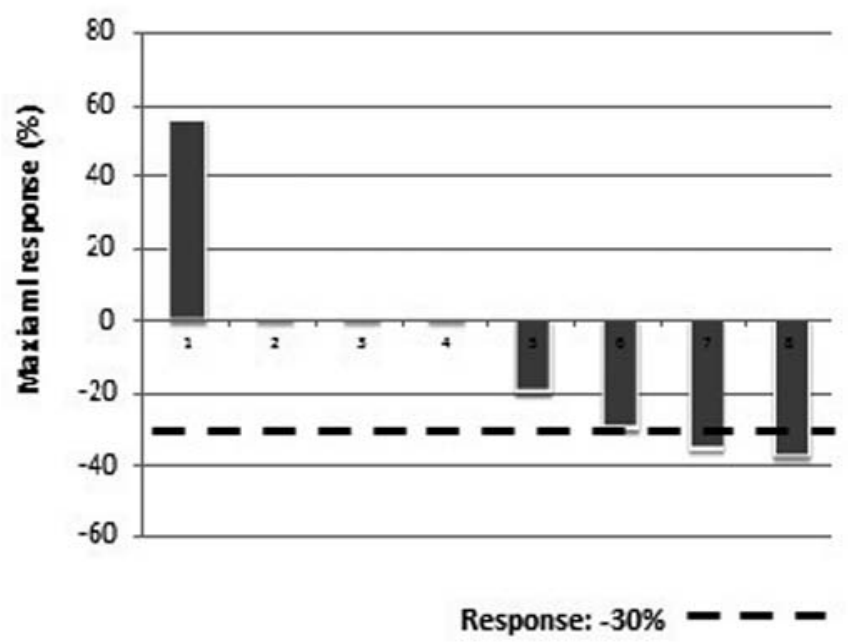

Fig. 1. Response of HNSCC to gefnitinib. Changes from baseline in radiographic measurements (RECIST) at the time of maximum response in patients treated with gefinitib. The mean change was $-8.4 \%$ (standard deviation, $30 \%$ ).

\section{Discussion}

In non-squamous-cell lung cancer, mutations in the EGFR gene occur at a relatively high frequency [24], but we have not found any mutations in the EGFR in our HNSCC patients. Today, in lung cancer, EGFR mutations are accepted as predictive markers of the benefit of gefitinib therapy [25, 26]. There is a significant superiority of gefitinib in patients bearing tumors with an EGFR mutation and an inferiority of gefitinib to conventional chemotherapy in non-mutated cancers. For HNSCC, we cannot confirm this result previously derived from lung cancer. In our pilot study, we did not find any relevant mutations in the EGFR although we observed a response rate of $37.5 \%$. The absence of EGFR mutations is consistent with the data of Loeffler-Ragg et al. [27] who observed only 1 mutation in 100 cases of HNSCC. Additionally, a Spanish study (31 patients), a study from Japan [28] and a study from Minneapolis (20 patients) did not identify any mutations in HNSCC [29] patients.

Similar to our trial, the phase II study by Cohen et al. [19] demonstrated an objective response rate of $11 \%$ in patients with recurrent and metastatic HNSCC who were treated with $500 \mathrm{mg} /$ day of gefitinib. In the study by Kirby et al. [30], it was observed that gefitinib was well tolerated and resulted in symptomatic improvement in one-third of the patients.

Similarly, the average PFS of 6.25 (minimum 1.3/maximum 10.8) months in our trial is in agreement with the previous studies. The median PFS and OS were 1.8 and 5.5 months, respectively, in the study by Cohen et al. [31] with $250 \mathrm{mg} /$ day of gefitinib, whereas they were 3.4 and 8.1 months, respectively, with $500 \mathrm{mg} /$ day of gefitinib [19]. With an OS of 7.4 (minimum 4.1/maximum 10.8) months, our results are in the same range. The quality of life of the patients improved temporarily during the first weeks of therapy. In our study, $50 \%$ of the patients ( 4 of 8 ) had a PFS of longer than 200 days, and the average PFS was 180 days in all patients analyzed.

Besides the retrospective study of Murray et al. [32] who analyzed 19 tumor specimens from patients treated with gefitinib, our trial is the only one to analyze the EGFR mutation status in a cohort of patients treated with gefitinib. Thus, even without a mutation in the EGFR, there is an objective response to gefitinib in HNSCC. There are, of course, some limitations to the interpretations being derived from this study, due to the small number of patients analyzed. While we cannot exclude that some rare patients with an EGFR mutation would benefit even more from gefitinib, we demonstrated
Table 2. EGFR mutation analysis and response to gefitinib

\begin{tabular}{llll}
\hline Patient & & Response & PFS, months \\
\hline 1 & $100 \%$ match gi41327737 & PR & 10.8 \\
2 & $100 \%$ match gi41327737 & PR & 6.7 \\
4 & position 2607 G to A (gi41327737 to gi11494376) & PR & 3.5 \\
5 & $100 \%$ match gi41327737 & SD & 5.8 \\
6 & $100 \%$ match gi41327737 & SD & 2.6 \\
7 & $100 \%$ match gi41327737 & SD & 8.6 \\
\hline
\end{tabular}


that there are objective responses in the absence of mutations in exons 19-21 of the EGFR. However, these results exclude the EGFR mutation status to predict the observed responses. Whether it would be a marker of even better responses than the ones observed in the very rare mutated tumors cannot be determined from our small pilot trial without any such case. Multiple predictive markers for the sensitivity or resistance to gefitinib in HNSCC have been investigated either in tumor cell lines or in cancer specimens. Amplification of the EGFR has been implied as a prognostic marker in HNSCC [33]. However, other EGFR/ErbB receptor family members may contribute to resistance to gefitinib [34]. In a genomic analysis, tumor cell line markers associated with epithelial-mesenchymal transition have been associated with resistance to gefitinib [35]. A proteomic analysis correlated gefitinib sensitivity with p-AKT and p-STAT3 activation in HNSCC cell lines and tumor specimens, which implies that p-AKT and p-STAT3 could serve as potentially useful biomarkers and drug targets [36]. Wheeler et al. [37] analyzed c-myc and cyclin D1 as predictors for gefitinib therapy. 10 paired tumor samples were tested by RT-PCR for c-myc and cyclin D1 gene expression. No correlation was found between changes in the expression of these genes and the clinical benefit of gefitinib. EGFRvIII has been proposed as a marker of resistance to therapy with cetuximab [38]; its role as a predictive marker for gefitinib is currently unknown. In summary, there is currently no reliable predictive marker identified for gefitinib therapy in HNSCC, and the establishment of such a marker is still a clinical need.

\section{Conclusion}

In HNSCC, EGFR mutation analysis seems not to be helpful in the prediction of benefit from gefitinib. Thus, there is still a need to identify other factors influencing the response to gefitinib.

\section{Acknowledgements}

We thank the patients and their families who participated in the study. This work was supported by the Krebsliga beider Basel and a pilot grant from the Schweizerische Arbeitsgemeinschaft für klinische Krebsforschung (SAKK).

\section{Disclosure Statement}

The authors declare that there are no conflicts of interest with respect to this study.

\section{References}

1 Carvalho AL, Nishimoto IN, Califano JA, Kowalski LP: Trends in incidence and prognosis for head and neck cancer in the United States: A site specific analysis of the SEER database. Int $\mathrm{J}$ Cancer 2005;114:806-816.

2 Constenla DO, Hill ME, A'Hern RP, Henk JM, Rhys-Evans P, Breach N, Archer D, Gore ME: Chemotherapy for symptom control in recurren squamous cell carcinoma of the head and neck. Ann Oncol 1997;8:445-449.

$\checkmark 3$ Argiris A, Li Y, Forastiere A: Prognostic factors and long-term survivorship in patients with recurrent or metastatic carcinoma of the head and neck. Cancer 2004;101:2222-2229.

4 Arnold DJ, Goodwin WJ, Weed DT, Civantos FJ: Treatment of recurrent and advanced stage squamous cell carcinoma of the head and neck. Semin Radiat Oncol 2004;14:190-195.

5 Hong WK, Schaefer S, Issell B, Cummings C, Luedke D, Bromer R, Fofonoff S, D'Aoust J, Shapshay S, Welch J, Levin E, Vincent M, Vaughan C, Strong S: A prospective randomized trial of methotrexate versus cisplatin in the treatment of recurrent squamous cell carcinoma of the head and neck. Cancer 1983;52:206-210.

6 Forastiere AA, Shank D, Neuberg D, Taylor SG 4th, DeConti RC, Adams G: Final report of a phase II evaluation of paclitaxel in patients with advanced squamous cell carcinoma of the head and neck: an Eastern Cooperative Oncology Group trial (PA390). Cancer 1998;82:2270-2274.

7 Guardiola E, Peyrade F, Chaigneau L, Cupissol D, Tchiknavorian X, Bompas E, Madroszyk A, Ronchin P, Schneider M, Bleuze JP, Blay JY,
Pivot X: Results of a randomised phase II study comparing docetaxel with methotrexate in patients with recurrent head and neck cancer. Eur J Cancer 2004;40:2071-2076.

8 Clavel M, Vermorken JB, Cognetti F, Cappelaere P, de Mulder PH, Schornagel JH, Tueni EA, Verweij J, Wildiers J, Clerico M, et al.: Randomized comparison of cisplatin, methotrexate, bleomycin and vincristine $(\mathrm{CABO})$ versus cisplatin and 5-fluorouracil (CF) versus cisplatin (C) in recurrent or metastatic squamous cell carcinoma of the head and neck. A phase III study of the EORTC Head and Neck Cancer Cooperative Group. Ann Oncol 1994;5: 521-526.

9 Vermorken JB, Mesia R, Rivera F, Remenar E, Kawecki A, Rottey S, Erfan J, Zabolotnyy D, Kienzer HR, Cupissol D, Peyrade F, Benasso M, Vynnychenko I, De Raucourt D, Bokemeyer C, Schueler A, Amellal N, Hitt R: Platinum-based chemotherapy plus cetuximab in head and neck cancer. N Engl J Med 2008;359:1116-1127.

10 León X, Hitt R, Constenla M, Rocca A, Stupp R, Kovács AF, Amellal N, Bessa EH, Bourhis J: A retrospective analysis of the outcome of patients with recurrent and/or metastatic squamous cell carcinoma of the head and neck refractory to a platinum-based chemotherapy. Clin Oncol (R Coll Radiol) 2005;17:418-424.

11 Santini J, Formento JL, Francoual M, Milano G, Schneider M, Dassonville O, Demard F: Characterization, quantification, and potential clinical value of the epidermal growth factor receptor in head and neck squamous cell carcinomas. Head Neck 1991;13:132-139.
12 Kalyankrishna S, Grandis JR: Epidermal growth factor receptor biology in head and neck cancer. J Clin Oncol 2006;24:2666-2672.

13 Kim ES, Khuri FR, Herbst RS: Epidermal growth factor receptor biology (IMC-C225). Curr Opin Oncol 2001;13:506-513.

14 Cowley GP, Smith JA, Gusterson BA: Increased EGF receptors on human squamous carcinoma cell lines. Br J Cancer 1986;53:223-229.

15 Sok JC, Coppelli FM, Thomas SM, Lango MN, Xi S, Hunt JL, Freilino ML, Graner MW, Wikstrand CJ, Bigner DD: Mutant epidermal growth factor receptor (EGFRvIII) contributes to head and neck cancer growth and resistance to EGFR targeting. Clin Cancer Res 2006;12:50645073 .

16 Mendelsohn J, Baselga J: The EGF receptor family as targets for cancer therapy. Oncogene 2000;19:6550-6565.

17 Baselga J, Averbuch S: ZD1839 ('Iressa') as an anticancer agent. Drugs 2000;60(suppl 1):33-40 discussion 41-42.

18 Ciardiello F, Caputo R, Bianco R, Damiano V, Pomatico G, De Placido S, Bianco AR, Tortora G: Antitumor effect and potentiation of cytotoxic drugs activity in human cancer cells by ZD-1839 (Iressa), an epidermal growth factor receptorselective tyrosine kinase inhibitor. Clin Cancer Res 2000;6:2053-2063.

19 Cohen EE, Rosen F, Stadler WM, Recant W, Stenson K, Huo D, Vokes EE: Phase II trial of ZD1839 in recurrent or metastatic squamous cell carcinoma of the head and neck. J Clin Oncol 2003;21:1980-1987. 
20 Soulieres D, Senzer NN, Vokes EE, Hidalgo M, Agarwala SS, Siu LL: Multicenter phase II study of erlotinib, an oral epidermal growth factor receptor tyrosine kinase inhibitor, in patients with recurrent or metastatic squamous cell cancer of the head and neck. J Clin Oncol 2004;22:77-85.

21 Giaccone G, Herbst RS, Manegold C, Scagliotti G, Rosell R, Miller V, Natale RB, Schiller JH, Von Pawel J, Pluzanska A, Gatzemeier U, Grous J, Ochs JS, Averbuch SD, Wolf MK, Rennie P, Fandi A, Johnson DH: Gefitinib in combination with gemcitabine and cisplatin in advanced non-smallcell lung cancer: a phase III trial - INTACT 1. J Clin Oncol 2004;22:777-784.

22 Lynch TJ, Bell DW, Sordella R, Gurubhagavatula S, Okimoto RA, Brannigan BW, Harris PL, Haserlat SM, Supko JG, Haluska FG, Louis DN, Christiani DC, Settleman J, Haber DA: Activating mutations in the epidermal growth factor receptor underlying responsiveness of non-small-cell lung cancer to gefitinib. N Engl J Med 2004;350:2129_ 2139.

23 Park JO, Lee SI, Song SY, Kim K, Kim WS Jung CW, Park YS, Im YH, Kang WK, Lee MH, Lee KS, Park K: Measuring response in solid tumors: comparison of RECIST and WHO response criteria. Jpn J Clin Oncol 2003;33:533-537.

-24 Tapia C, Savic S, Bihl M, Rufle A, Zlobec I, Terracciano L, Bubendorf L: [EGFR mutation analysis in non-small-cell lung cancer: Experience from routine diagnostics]. Pathologe 2009;30:384392.

25 Mok TS, Wu YL, Thongprasert S, Yang CH, Chu DT, Saijo N, Sunpaweravong P, Han B, Margono B, Ichinose Y, Nishiwaki Y, Ohe Y, Yang JJ, Chewaskulyong B, Jiang H, Duffield EL, Watkins CL, Armour AA, Fukuoka M: Gefitinib or carboplatin-paclitaxel in pulmonary adenocarcinoma. N Engl J Med 2009;361:947-957.
26 Mitsudomi T, Morita S, Yatabe Y, Negoro S, Okamoto I, Tsurutani J, Seto T, Satouchi M, Tada H, Hirashima T: Gefitinib versus cisplatin plus docetaxel in patients with non-small-cell lung cancer harbouring mutations of the epidermal growth factor receptor (WJTOG3405): an open label, randomised phase 3 trial. Lancet Oncol 2010; 11:121-128.

27 Loeffler-Ragg J, Witsch-Baumgartner M, Tzankov A, Hilbe W, Schwentner I, Sprinzl GM, Utermann G, Zwierzina H: Low incidence of mutations in EGFR kinase domain in Caucasian patients with head and neck squamous cell carcinoma. Eur J Cancer 2006;42:109-111.

28 Ali MAL, Gunduz M, Nagatsuka H, Gunduz E, Cengiz B, Fukushima K, Beder LB, Demircan K, Fujii M, Yamanaka N: Expression and mutation analysis of epidermal growth factor receptor in head and neck squamous cell carcinoma. Cancer Sci 2008;99:1589-1594.

29 Lemos-González Y, Páez de la Cadena M, Rodríguez-Berrocal F, Rodríguez-Piñeiro A, Pallas E, Valverde D: Absence of activating mutations in the EGFR kinase domain in Spanish head and neck cancer patients. Tumor Biol 2007;28:273279.

30 Kirby AM, A'Hern RP, D'Ambrosio C, Tanay M, Syrigos KN, Rogers SJ, Box C, Eccles SA, Nutting CM, Harrington KJ: Gefitinib (ZD1839, Iressa) as palliative treatment in recurrent or metastatic head and neck cancer. Br J Cancer 2006;94:631-636.

31 Cohen EE, Kane MA, List MA, Brockstein BE, Mehrotra B, Huo D, Mauer AM, Pierce C, Dekker A, Vokes EE: Phase II trial of gefitinib $250 \mathrm{mg}$ daily in patients with recurrent and/or metastatic squamous cell carcinoma of the head and neck. Clin Cancer Res 2005;11:8418-8424.

32 Murray S, Linardou H, Razis E, Pectasidis D, Fountzilas G: Screening for EGFR mutations in patients with head and neck cancer treated with gefitinib on a compassionate-use program: a Hellenic Cooperative Oncology Group study. Ann Oncol 2006;17(suppl 9):578.

33 Temam S, Kawaguchi H, El-Naggar AK, Jelinek J, Tang H, Liu DD, Lang W, Issa JP, Lee JJ, Mao L: Epidermal growth factor receptor copy number alterations correlate with poor clinical outcome in patients with head and neck squamous cancer. J Clin Oncol 2007;25:2164-2170.

34 Erjala K, Sundvall M, Junttila TT, Zhang N, Savisalo M, Mali P, Kulmala J, Pulkkinen J, Grenman R, Elenius K: Signaling via ErbB2 and ErbB3 associates with resistance and epidermal growth factor receptor (EGFR) amplification with sensitivity to EGFR inhibitor gefitinib in head and neck squamous cell carcinoma cells. Clin Cancer Res 2006;12:4103-4111.

35 Frederick BA, Helfrich BA, Coldren CD Zheng D, Chan D, Bunn PA, Raben D: Epithelial to mesenchymal transition predicts gefitinib resistance in cell lines of head and neck squamous cell carcinoma and non-small cell lung carcinoma. Mol Cancer Ther 2007;6:1683-1691.

36 Pernas FG, Allen CT, Winters ME, Yan B, Friedman J, Dabir B, Saigal K, Mundinger GS, $\mathrm{Xu} \mathrm{X}$, Morris JC: Proteomic signatures of epidermal growth factor receptor and survival signal pathways correspond to gefitinib sensitivity in head and neck cancer. Clin Cancer Res 2009;15:23612372

37 Wheeler RH JD, Sharma P, et al.: Clinical and molecular phase II study of gefitinib in patients (pts) with recurrent squamous cell cancer of the head and neck ( $\mathrm{H}$ and $\mathrm{N} \mathrm{Ca}$ ). ASCO Annual Meeting 2005.

38 Wheeler S, Suzuki S, Thomas SM, Sen M, LeemanNeill RJ, Chiosea S, Kuan C, Bigner D, Gooding W, Lai S: Epidermal growth factor receptor variant III mediates head and neck cancer cell invasion via STAT3 activation. Oncogene 2010;29:5135-5145. 